\title{
Putta as an Albatross and as a Catalyst in Praneshacharya's Transformation in U. R. Anantha Murthy's Samskara
}

\author{
Osayimwense Osa \\ Virginia State University, Petersburg, USA
}

\begin{abstract}
Samskara by U. R. Anatha Murthy who passed in 2014 belongs to great literature. A perennially changing and challenging text, Samskara is included in Oxford India Perrenials - Classics from a century of Oxford University Press (OUP) India's rich and diverse publishing tradition. A masterpiece of Indian, Asian, and World literatures, which was originally published in 1965 as Manohara Grantha Mala, Dharwar and translated into English in 1976 as Samskara, has received significant scholarly attention capped with Samskara: A Critical Reader edited by Kailash C. Baral, D., Venkat Rao, and Sura P. Rath (2009), the first volume of its kind to be published on one of the classics of Indian literature. The protagonist of the novel, Praneshacharya, the spiritual leader of a community of conservative Brahmins, experiences and realizes certain natural and universal elements that can strongly undergird his calling as a spiritual head of a community after committing adultery at an unguarded moment with a prostitute. An understanding and appreciation of the reality of natural desires need not be accompanied by religious dogma. At the end of the novel which does not really have any closure, he is beginning to honestly position himself to appreciate and preserve humanity and spirituality in a more robust manner rather than in his past stance of asceticism and sticking narrowly to the letter of his religion. What is attempted here is a critical examination of Putta as an albatross and as a catalyst in the beginning transformation of the protagonist from a narrow life of asceticism and self-denial into a fuller life of integration of spirituality and humanity.
\end{abstract}

Keywords: guilt, albatross, catalyst, rebirth, transformation, integration, spirituality, humanity

\section{Introduction}

As an allegory, U. R. Anantha Murthy's Samskara is arguably a literary genre where things are represented by other things. Putta assumes the proportion and dimension of an albatross for Praneshacharya in his transformation and self-discovery in this novel. Used metaphorically, the word "albatross" is a perpetual psychological shackle or burden that cannot be avoided, or annihilated on one's own. In Samuel Taylor Coleridge's famous poem, "The Rime of the Ancient Mariner", the albatross is the symbol of the curse on the Mariner. It is the root or origin of the expression, "hang an albatross around his neck". Unlike the Mariner who shoots the albatross with his crossbow in "The Rime of the Ancient Mariner", Praneshacharya does not shoot Putta with any bow and arrow. Putta as an "albatross" sticks to Praneshacharya like a leech even promising at the end of the novel to see him the next day. This essay seeks to critically examine Putta as Praneshacharya's albatross and catalyst of transformation.

Osayimwense Osa, M.A. Ed.D Professor of English, Department of Languages and literature, Virginia State University, Petersburg, USA. 
Samskara opens with a description of the pious Brahmin Praneshacharya's unfailing daily routine of taking care of his invalid wife, Bhagirathi, and his regular trip to worship at the Maruti temple, and ends with him being physically pushed by Putta, a Malera (product of a lower caste and a Brahmin) into a wagon enroute to Durvasapura. Without Praneshacharya, there is no novel, Samskara. He dominates the novel from the first page as a decisive and independent mind taking care of his invalid wife, to the last page of the novel as an indecisive and dependent mind unsure of where he is going to. As a matter of fact, "Praneshacharya" can function very well as the title of the novel as does the novel's real title, Samskara.

Pranesharya is the "Crest-Jewel of Vedic Learning" and the great Brahmin of the Durvasapura agrahara community. But Praneshacharya's Brahminism extends beyond the normal parameters and his self enforced celibacy is a manifestation of his excessive zeal for purity. His heart rejoices and overflows with gratitude for his bed-ridden wife who, by becoming an invalid, has obliged him with the opportunity of becoming more perfect and mellower on the road to salvation and he constantly rejoices in his fate (Nagarajan, 1971). For a quarter of a century, Praneshacharya has lived by choice, as a celibate. His invalid and sickly wife described as "Bhagirathi's body, a dried-up wasted pea-pod" provides no sexual pleasure or thought for him, and he was not perturbed by it. He enjoys it hoping steadfastly that this barren situation would pave the way for him to achieve all in a heavenly bliss. According to the author, Anantha Murthy (1976) very early in the novel proudly swelled a little at his lot, thinking "By marrying an invalid wife, I get ripe and ready" (p. 4).

But after his one time brief sexual encounter with Chandri, a prostitute that is not favorably regarded in their local Durvasapura Bramin Brahmin community (agrahara), he is no longer at ease with himself and with his community as well. The rest of the novel essentially encapsulates the immediate and long term horrors, fears, and uncertainties of Praneshacharya. His psychological confusion is crystallized in his statement,

All things indirect must become direct. Must pierce straight in the eye. But it's agony either way. If I hide things all through life I'll be agonized by the fear of discovery, by some onlooking eye. If I don't, I'll muddy the lives of others by opening up and exposing the truth to the very eyes my Brahminhood has lived and grown by. (p. 132)

Bruised by guilt, mental torture, and agony, Praneshacharya sinks completely into a condition reminiscent of Christian's "Slough of Despond" in the 17th century allegory, The Pilgrim's Progress, by John Bunyan (1628-1688). He does need some degree of support to avoid complete nervous breakdown. In John Bunyan's The Pilgrim's Progress, to come out of his intense depression, the protagonist, Christian, is assisted by Help who tells him,

This miry Slough is such a place as cannot be mended. It is the descent whither the scum and filth that attends conviction for sin doth continually run, and therefore it is called the Slough of Despond; for still as the sinner is awakened about his lost condition, there arises in his soul many fears and doubts, and discouraging apprehensions, which all of them get together, and settle in this place. ${ }^{1}$

Like Help in Pilgrim Progress, it is Putta, without clearly realizing it, who helps Praneshacharya out of his own "Slough of Despond"-his guilt ridden conscience arising from his "one night stand" with the beautiful prostitute, Chandri, wife of Naranapa, a fallen reprobate Brahmmin.

\footnotetext{
1 The Pilgrim's Progress - An Airmont Classic- specially selected for the Airmont Library from the immortal literature of the world. THE SPECIAL CONTENT New York: Airmont Publishing Company, inc., 1969, p. 23.
} 


\section{Praneshacharya and the Women, Bhagirathi, Chandri, and Padmavati}

Unlike his sickly wife that he takes care of without any sexual fulfilment, Chandri the prostitute of lower caste takes care of him, albeit briefly, in the dark forest near the Maruti temple, and with momentous consequence. Why did Praneshacharya become "a bundle of confusion" after his brief affair with Chandri? According to Meenakshi Mukherjee (2009), it is allegorically significant that this act (sleeping with Chandri) which opens out a new world of naturalness and wholeness to the Acharya happens in the forest—outside the frame of stratified society (p. 90). Before this experience, it was all calm for Praneshacharya, albeit, an uneasy one. Married at 16 when his virility was naturally very strong, he only represses his sexual feelings in his desire for salvation through a sexless marriage to an invalid young woman. Repressed for more than two decades, his sexuality comes alive at an unguarded moment with Chandri. The brief union with Chandri releases his repressed pent up sexual instinct and desire. Chandri is a symbol rather than a realistic character embodying a natural wholeness and an instinctive spontaneity which Praneshacharya can never achieve (Mukherjee, 2009, p. 90). After their union in the forest, Chandri is still as ever, completely free as the air, walks home and cremates unceremoniously Naranapa's body with the help of Muslims. After the unceremonious cremation, Chandri mourns naturally and goes home, collects a few of her valuable, "a few of her silk saris in a bag, bundled up the cash in the box and the gold ornaments the Archarya had returned", and decides to catch the morning bus to Kundapura "walking towards the motor route in the forest path with her bundle in her hands" (p. 70). Unlike her, Praneshacharya is guilt ridden and confused walking aimlessly. Unlike the decisive Chandri who collects her valuables and leaves Durvasapura for Kundapura, the indecisive Praneshacharya leaves everything behind and walks away from Durvasapura which he half-heartedly returns to not knowing exactly what he is going to do there or what he is going to tell the other Brahmins.

Far from bringing shame and disgrace to Praneshacharya, Chandri in fact is arguably a symbol of liberation from his self-imposed celibacy. He physically and spiritually unites in a sexual act with Chandri that he earlier on could not speak to primarily to avoid being polluted. It is this union, albeit unpremeditated, that finally opens Praneshacharya's eyes to real life which he has hitherto denied significantly. His ordeal actually begins at this juncture of the novel. Although he regrets his fall in his adultery with Chandri, it is in this fall his adultery - that stimulates him into to a thorough and painstaking reassessment of his own past, present, and possible future direction as the super pundit Brahmin of Durvasapura agrahara.

What causes rock-solid Praneshacharya to sleep with Chandri who the agrahara people scorn as a prostitute? Is it her physical beauty that is irresistible? "While the auspicious Brahmin wives, with their dwarfish braids and withered faces, wore mandara with jasmine, Chandri wore her black-snake hair coiled in a knot and wore the flowers of the ember-champak and the heady fragrant screw-pine" (p. 15). It is Chandri that he instantly runs to for support soon after his wife's death. After Chandri's disappearance from the novel, she continues to linger strongly in Praneshacharya's memory. In fact, Chandri becomes a solid part of his psyche, a standard or yardstick for measuring what he considers as true womanhood. He recalls his memory of Chandri any time he sees a woman he fancies.

Did he take her then out of compassion?...

The Acharya's fantasy dragged in all the untouchable girls

he'd never thought of; stripped them and looked at them...

His hands itched to go caress Belli's breasts, thirsting for

new experience. So far he didn't even live; doing only what was 
done, chanting the same old mantra, he had remained inexperienced. (p. 82)

The last woman that he sees toward the end of the novel is Padvamati who was introduced to him by Putta—possibly to spend the night with. But Praneshacharya finds the idea and situation-spending a night with another prostitute-awkward and uneasy against the backdrop of his memory of Chandri. Awkward and out of place for the Brahmin dinner in Brahmin temple in Melige that Putta encouraged him to join, the memory of Chandri rushes into his mind in connection with the possibility of a rendesvouz with an attractive, respectable, and uncommon prostitute, Padmavati:

Is it the kind of fear that will be quenched if I sleep with Padvamati tonight? Will it be quenched if I go live with Chandri? What's my decision worth? Am I forever to be a ghost of a man, hovering in indecision? I wish Putta was here. (p. 128)

\section{Putta, Bosom-Friend of the Present}

In this dramatic monologue, a long piece of dialogue by one character that reveals the character's inner feelings, we see the intense and chaotic psychological state of Praneshacharya:

I suddenly turned in the dark of the forest. But my dilemma, my decision, my problem wasn't just mine, it included the entire agrahara.... Did I feel such conflict when I lay with Chandri? Did I decide it after pouring and measuring and weighing? That decision, that act gouged me out of my past world, the world of the Brahmins, from my wife's existence, my very faith. The consequence, I'm shaking in the wind like a piece of string...the root of all my anxiety is because I slept with Chandri as in a dream. Hence the present ambiguity, this Trishanku-state. I'll be free from it only through a free deliberate wide-awake fully-willed act. Otherwise, a piece of string in the wind, a cloud taking on shapes according to the wind. I've become a mere thing. By an act of will I'll become human again. I'll become responsible for myself...I'll give up this decision to go where the legs take me, I'll catch a bus to Kundapura and live with Chandri. I'll then end all my troubles. I'll remake myself in full wakefulness... (pp. 109, 110)

What we need to understand is that in facing his failure, guilt, and shame emanating out of his unpremeditated sexual intimacy with Chandri, Praneshacharya the pious spiritual leader of Durvasapura, needed strength and courage-one that is completely realistic and human. Shackled by a heavy burden of guilt and wandering aimlessly, Praneshacharya encounters a calf, a nameless farmer, and finally, an irrepressible and ebullient young man, Putta, who assertively and aggressively introduces himself, "I am Putta, of the Maleras" indicating clearly his destination-"going for the car festival at Melige" (p. 101) to the unease and chagrin of Praneshacharya who wanders about not knowing exactly where he is going to.

The author's description of Putta leaves us in no doubt that he brings Putta into the novel as a strong and decisive character to provide some needed modicum of direction to a confused and spiritually disturbed Brahmin, but he does not emerge as a full rounded flesh and blood character: "A very long nose gave the face the look of a strong-willed man. His close-set eyes sharpened his gaze and made one squirm under it" and according to the author, "though Putta spoke the usual words of any villager opening a conversation, Praneshacharya squirmed" (p. 102). This essentially is the situation from the time Putta meets Praneshacharya until they part at the end of the novel when Putta pushes him into the covered wagon going to Durvasapura. Even the parting is temporary because Putta promised to see him the next day.

Unlike the calf that smelled Praneshacharya's neck, Putta who is ignorant of Praneshacharya's adultery (sleeping with Chandri) and ignorant of the fact that he has just lost his wife, Bhagirathi, provides more direct flesh and blood relationship with him and for him in his depression and confusion. Like an albatross, 
Putta of the Maleras (a product of an intercaste marriage) stuck to Praneshacharya like a sin of the past. That was his way: if you stop, he'll stop too; sit, he'll sit. Walk faster, he'll walk faster; if slower, slower, Won't leave your side. Praneshacharya was getting quite upset. He'd like to be alone, sit with his eyes shut, and think for himself-but this fellow Putta is rattling away ceaselessly. The Acharya gives him no quarter, yet he clings. Because he doesn't know this is Praneshacharya, crest-jewel of Vedanta, etc., he is behaving as he would with a common mendicant Brahmin on his beggarly rounds. (p. 106)

In spite of almost becoming a nuisance to Pranshacharya, he provides some degree of sanity and human companionship in sharing with Praneshacharya. He shares interesting riddles with him and he shares with him some of his "brown sugar and coconut pieces" which Praneshacharya really needed because of his intense natural hunger for food at the time. According to the author, "Wherever he went, whatever happened, human company seemed to cling to his back like one's lot earned in a past life" (p. 93). Putta represents that human company. The author's choice of brown sugar is deliberate. Brown sugar has always provided energy for humans. In addition, in India, brown sugar is a popular drug (http://www.deaddictioncentres.in/glossary/brown-sugar/). Here in the novel, regardless of the fact that it is a drug, Putta's sharing it with Praneshacharya brings the two of them closer in their walk and in their talk. Putta unceremoniously eggs him on to break one taboo after another and succeeds in desacralizing his ritual space. Praneshacharya accepts it as part of his rehabilitation...Putta leads him by the nose, as it were, through one pollution after another (Parsatharathy, 1994, p. 196). By tugging at him ceaselessly or endlessly particularly when it is clear that Praneshacharya was fed up with his company, Putta is downright a nuisance to him especially at the beginning of their association.

Praneshacharya needs a paradigm shift which he has slowly and steadily begun to embrace after his secret sexual affair with Chandri, and after the death of his wife. His asceticism begins to wane as reflected in his walking away from his spiritual domain, Durvasapura, at a time when he is needed most by the agrahara plagued by spiritual confusion not knowing how to dispose of the corpse of a reprobate Brahmin, and plagued by an epidemic resulting in the death of some of them. His abandoning his domain at this crucial time is almost irresponsible. It is, however, definitely not an easy paradigm shift particularly for a pious and well-educated spiritual leader, like Praneshacharya, the "Crest-Jewel of Vedic Learning" who has lived all his life strictly by a Brahmin code of conduct—rules of his orthodox, traditional, and conservative Brahminism. Does Putta come to strengthen Praneshacharya who is at the lowest point of his life and career as the Crest-Jewel of Vedic Learning and spiritual leader of Durvasapura-committing adultery and followed very closely by losing his wife of 25 years?

Although Putta is introduced relatively late toward the end-Part 3 of Samskara, he is important as an albatross and as a catalyst in the slow but steady transformation of Praneshacharya from a rigid, ascetic, and narrow-minded Brahmin to a full human being in touch with reality. A. R. Anantha Murthy concludes Part 2 of the novel with the protagonist, Praneshacharya's seeming determination to walk away from the past, the traditional agrahara in Durvasapura, and all that orthodox Brahminism represented: The Acharya did not return to the agrahara after his wife's cremation. He thought of nothing, neither the fifteen gold-lace shawls in his box, the two hundred rupees, nor the basil-bead rosary done in gold given by the monastery. Meaning to walk wherever his legs took him, he walked towards the east (p. 87) where the sun rises-an indication of Praneshacharya looking for a new beginning or new rise or new lease on life. This search or quest for a new beginning is not easy for Praneshacharya after his fall and its attendant guilt, shame, and embarrassment. 
Embarrassment, like shame, is a consequence of a humiliating display of personal fallibility; it arises when the coherent self one tries to project is at odds with the imperfect self one involuntarily reveals (Greaney, 2003, p. 3). In his quest for a new beginning, it does seem that an incredibly embarrassed Praneshacharya has to get assistance from various characters particularly from Putta, a Malera Brahmin, lower than Pranshacharya in the caste ladder. His seeming determined walk away from Durvasapura is a labored one- "dragging his feet wearily" without thinking "of place and direction for a long time". Material wealth represented in "the fifteen gold-lace shawls in his box, the two hundred rupees" and spirituality and religion represented in "the basil-bead rosary done in gold given by the monastery" at this juncture of the novel are meaningless and have significantly and considerably lost their appeal, attraction, and charm for Praneshacharya. His invalid wife of more than two decades suddenly becomes ugly and absolutely unappealing and disgusting after his unpremeditated sexual union with Chandri in the forest. At the end of the beaten path of a quarter century of doctor-patient relations, of affection and compassion, he seemed to see an abyss. He shivered in an attack of nausea (p. 75). If his wife had not passed away soon after his secret affair with Chandri in the dark forest in the night, Praneshacharya's human nature and his relationship perhaps would have still remained a sterile one with his sexuality bottled and stifled up. Praneshacharya's career can arguably be said to be in two phases in the novel-before, and after his secret adulterous affair with Chandri in the forest. After sleeping with Chandri, Praneshacharya begins a transformation that is clearly traumatic particularly at the beginning. Even at the end of the novel, the trauma does not seem to have completely lessened or reduced. The trauma only begins ebbing very slowly at the end of the novel with the assistance of Putta, the powerful catalyst in the slow but steady transformation of Praneshacharya.

\section{Putta Pushes Praneshacharya Into the Covered Wagon (Italics Mine, for Emphasis)}

Unlike the decisive prostitute, Chandri who needs no help to board her bus to Kundapura, Praneshacharya, the fallen Brahmin, needs all the physical and psychological help provided by Putta to board the wagon on its way back to Durvasapura. Mukherjee (2009) rightly observed that

he lacks the will to make an existential decision and that his journey back to Durvasapura happens rather than is voluntarily undertaken. The cart going in that direction has only one seat, so Putta is left behind and Praneshacharya moves towards his third climatic moment of confession which is essentially outside the scope of the novel. (p. 97)

Arguably, in the circumstance here, Putta is not really left behind. Mukherjee's observation leaves out some significant drama in the last scene. This same significant drama is also left out in the movie version of the novel. As a matter of fact, the scene in the movie version of Samskara seems to depict Praneshacharya as calm, confident, and in control of the situation. But it is not like this at all in the novel. He is indecisive and confused while Putta remains more forceful and more decisive to the point of physically "shoving" Praneshacharya into the cart:

"Do you have place for two? We want to go to Durvasapura" said Putta

"But we've place only for one."

Putta took hold of his hand and said, "You'd better go, Acharya-re."

"No, no. Let's go together, on foot," said the Acharya

Putta insisted on Praneshacharya getting in, and pushed him in (my emphasis). Praneshacharya, not seeing any way out, climbed into the cart and sat down. (pp. 137, 138) 
To take hold of someone's hand suggests that the person whose hand is held is either a child or a stranger or is naïve and needs guidance not to be lost. Is this not the picture here of Putta and Praneshacharya?

Clearly, Praneshacharya does not want to go alone to Durvasapura as if he is afraid. His emphatic "No, no. Let's go together, on foot" suggests that he is still not ready to stand firm on his feet and be. Is it not ridiculous that he wants them to go on foot for miles? Putta senses his weakness, reluctance, and indecision, and gives him his emphatic assurance, "I'll come and see you tomorrow" (p. 137). Unlike Chandri who decisively leaves Durvasapura for Kundapura after their affair, Praneshacharya is returning to the same community, Durvasapura, still weak and indecisive. Is he going to confess to his fellow Brahmins that he partook of Narranapa's pleasure in sleeping with Chandri and that he is not a super spiritual leader Brahmin after all? The author brings the novel to his own special "close" by not giving any definitive conclusion with "Praneshacharya waited, anxious, expectant" (p. 138).

\section{Putta, and Praneshacharya's Return to Durvasapura}

Certainly, Praneshacharya has not completely forgotten his Brahminism or his ascetic way of life after his sexual union with Chandri, and one does not expect him to. He is still pulled between his past and present, and he is not still strong enough to determine how he would deal with the future. Plagued by fear, timidity, and indecision, Praneshacharya at the end of the novel is like T.S. Eliot's J. Alfred Prufrock in "The Love Song of J. Alfred Prufrock" who cannot decide with firmness as revealed in his own dramatic monologue: "Do I dare disturb the universe? In a minute there is time. For decisions and revisions which a minute will reverse".

To assert that "the structure of expectation that survives the novel is in fact the structure of an 'innocent' escapism that will not turn back for fear of accountability and transformation" is a result of a superficial reading and reflection. Why a brilliant mind like Radhakrishnan (2009) came to that conclusion is difficult to grasp. According to him:

Why will Praneshacharya not return to the agrahara and re-recognize himself in front of everybody and accord Naranappa's body the respect it deserves? Instead the novel simulates an anomie that does not exist except in the head of an unregenerate Brahmin. There really is no narratological crisis here: all that is required is a recantation of Brahmanism, and a re-understanding of what it means to be human (my emphasis, pp.148-149)

To label Praneshacharya as "an unregenerate Brahmin" is hard and unfair. He is definitely not like the reprobate Brahmin, Naranapa, in Durvasapura. He is quite honest and pious but only made a mistake at an unguarded moment—committing adultery with a prostitute in a lonely dark forest in the night. His ordeal is an excellent illustration of "a moment's indiscretion can entail a lifetime of regret". There is no indication that Praneshacharya "will not return to the agrahara". Praneshacharya finally returns in a covered wagon to the agrahara at the end of the novel. If Praneshacharya had recanted Brahmanism and clearly and mechanically demonstrated "a re-understanding" of what it means to be human at the end of the novel, Samskara as a novel would not have been an accomplished and satisfying work of fiction, and arguably would not have got the world wide critical attention that it has got and continues to get. Unlike Radhakrishnan's rather simplistic solution, "all that is required is a recantation of Brahmanism, and a re-understanding of what it means to be human", the reasoning of Mukherjee (2009) is more appealing. According to her,

when he (Praneshacharya) sets out on his journey in the third section of the novel he is really in search of the residual self that remains after the outer shells are discarded.... It is the universal problem of a man who has equated himself with a particular role for so long that the role becomes his self, and without the role, he feels lost. (p. 84) 
We certainly do not expect the great Brahmin, Praneshacharya, to throw overboard in a second what he has learned and lived all his life before his unplanned and sudden sexual encounter with Chandri. To do so would have been catastrophic for the plausibility and success of Samskara as a novel, and for the success of Anantha Murthy as a novelist in control of his art. In fact, how this was handled by the novelist is a major success of the novel.

Against the backdrop of life, vitality and energy represented in the Melige festival—an incessant jumble of Sanskrit scripture on the temple chariot, the raucous talk of the Smarta Brahmins, a gramophone song from the coffee shop, the Bombay Box man dancing and showing his pictures, an acrobat sliding in a flash down the slope of a rope and coming down to his feet with a salute, Praneshacharya is alone because he is unable to participate and enjoy the festivities of the town Melige's festival. According to the author, "in between he must decide here now. Decide to give up a quarter-century of discipline and become a man of the world? No, no" (p. 126). Unlike Praneshacharya, Putta who is not shackled by guilt or rigid tradition participates in the festivities. He watches the show by the Bombay Box man and throws coins to the lepers who rush to him for more coins but Praneshacharya finds all unpleasant: "Praneshacharya, not able to stand the pathetic cries of the invading beggars all around him, walked into the temple in a daze" (p. 127). He is uneasy going alone into the temple to partake of the temple dinner and wants Putta to accompany him - "I can't stir without Putta...He'd never before felt such a dread of being alone" (p. 109). Is it not interesting to note that it is Putta who now reminds him, that he is not a Brahmin but a Malera who does not have the guts to sit and eat a meal with a Brahmin like Praneshacharya and the other Brahmins in the temple?

Truly, one does not expect Praneshacharya to give up "a quarter century of discipline and become a man of the world" overnight. Tradition cannot be given up overnight, however, desirable this may be. In traditional societies, like India, the stroke of the pen, whether the writers or the legislators, accomplishes little. Caste is a fact of existence in secular India, and untouchability, though illegal, has not entirely disappeared in spite of Gandhi's Himalayan efforts to clean the brahmanical cowsheds (Parthasarathy, 1994). So, it is that we should not expect Praneshacharya to completely discard his old life in one fell swoop. Without Putta, Praneshacharya could have probably wandered aimlessly for a long time or forever. Gupta (1980) observed that Praneshacharya's coldness and aloofness gradually wither away, and he begins to respond warmly to human affection. Impatient at and distrustful of Putta at first, he slowly warms to him and even begins to feel helpless without him (pp. 22-23). But for how long will he continue to "feel helpless" without Putta, or continue to depend on Putta, as a catalyst in his beginning transformation from a narrow life of asceticism to a broadminded life of humanity and realism.

There is no doubt that Putta would likely honor his promise to see him the next day.

But how and when can Praneshacharya as a Brahmin and spiritual leader complete his realistic assessment and reappraisal of his fall through his brief sexual affair with Chandri, and the asceticism and celibacy that he had imposed on himself for a quarter of a century, and confidently stand on his feet like the "sheep" or follower in Psalm 23 where the Lord is metaphorically called the shepherd? Like the follower in Psalm 23 whose faith in the Lord is growing, Praneshacharya's faith in humanity is also growing in Samskara. The philosopher Paul Tillich defined faith as "the state of being ultimately concerned", the condition of giving oneself over to what promises total fulfilment, the object of such faith being anything from a deity to love, power, or money. In this latter sense, faith seems a "universal phenomenon": While its objects may differ, most everyone may have it (Gottcent, 1986). At the end of Psalm 23, the speaker's knowledge of the Lord and of himself/herself has 
matured and he/she can confidently assert: "Surely goodness and mercy shall follow me. All the days of my life; and I shall dwell in the house of the Lord for ever. But this kind of confidence and affirmation is lacking in Praneshacharya at the end of the novel which does not really have a closure.

\section{Conclusion-“First let me try it all (confession) on Putta” and What Next?}

Praneshacharya has recognized the beauty and grace of Chandri the prostitute, the beauty and grace of the simple calf that breathed on his neck and jostled him out of his wandering and stupor/trance. By the end of the novel, he begins to recognize and appreciate the beauty and grace of Putta, the Malera. He begins to see him as a support and as a precursor audience to rehearse his confession before his possible full confession to "all those Brahmins" in Durvasapura:

Shall I tell him my true dilemma?... Then it suddenly seemed a good thing to have Putta for company. "How can I face all those Brahmins alone? First, let me try it all on Putta, bosom-friend of the present. Let's see how I look in his eyes - that may be a good way of doing it". (p. 117)

Clearly, Praneshacharya considers his confession of his adultery with Chandri and perhaps all the taboos that he has broken significant enough to warrant doing a rehearsal or practice for his first audience, Putta, before his actual and real confession before the whole agrahara community. However, we have not seen his prepared speech or confession to rehearse.

Is Praneshacharya's albatross about to fall or drop from his neck? In "The Rime of the Ancient Mariner", it is only when the Mariner sees a group of water snakes, recognises how beautiful they are, and blesses them in his heart that the curse and guilt he brought on himself and the boat crew come to an end; and the albatross, which has been hung around his neck, drops. The Mariner rows to shore, reaches land, where he confesses his sin. For his penance, he is told that he must wander the earth, retelling his tale to absolve his sin and to teach others not to make the same mistake that he made. Praneshacharya thinks about confessing his sin when he gets back to Durvasapura, and then "Putta as his albatross" may fall from his neck. And what will be his penance? His honest and contrite confession of his adultery with Chandri and his shortcomings as an ascetic Brahmin could bring him absolution. But at the end of the novel there is no note of affirmation to confess but only his own thought to rehearse his confession before his "bosom friend of the present." "Bosom friend of the present" suggests a fleeting one that might not be permanent like Chandri whose image has been indelibly etched in his memory. He has not summoned any courage to confess his crime to Putta who represents his albatross. This is why Putta who represents his albatross has not dropped out of his life. He will be with him the next day as he promised in their temporary parting. In their next meeting, perhaps Praneshacharya will rehearse his confession to Putta as his prelude to his full confession of his adultery with Chandri to Durvasapura community. Be this as it may, it is clear that Praneshacharya sees Putta as one that he can confess to and confide in as well, thereby keeping his transformation process going.

Until Praneshacharya confesses his sin, he will not have any peace of mind. His confession is a prerequisite for penance. Could his penance be like that of the Mariner in Coleridge's "A Rime of the Ancient Mariner"- to wander the earth to retell his tale and confession and teach others to learn from his mistake or shortcoming? In all probability, Praneshacharya's penance will likely take into account his personal situation and serve to support his spiritual growth. But this is outside the scope of the novel. In his homecoming or return to Durvasapura, the direction of Praneshacharya's realization of the reality of the human world and his 
beginning faith in the human or existential world with or without Putta as a catalyst and/or as an albatross in his total transformation is a matter of critical conjecture.

\section{References}

Aikant, S. C. (2011). Burden of the past: U. R. Anantha Murthy's Samskara. Summerhill: IIAS Review, 28, 28-36.

Anantha Murthy, U. R. (1976). Samskara. Oxford, New York: Oxford University Press.

Gottcent, J. H. (1986). The Bible-A literary study. Boston: Twayne Publishers.

Greaney, M. (2003). Lord Jim and embarrassment. In A. H. Simmons \& J. H. Stape (Eds.), Lord Jim: Bicentennial essays (pp. 1-14). Atlanta, GA: Rodopi.

Gupta, R. K. (1980). The fortunate fall. The International Fiction Review, 7(1), 20-23.

Mukherjee, M. (2009). Samskara. In K. C. Baral, D. V. Rao, \& S. P. Rath (Eds.), U. R. Anantha Murthy's Samskara: A critical reader. Delhi: Pencraft International.

Nagarajan, S. (1971). Samskara. Indian Writing Today, 17, 117-123.

Parsatharathy, R. (1994). The passing of the Brahman tradition. In B. S. Miller (Ed.), Masterworks of Asian literature in comparative perspective. New York: M. E. Sharpe.

Pillai, S. (2014). Back to the future: Tracking the moral imperative in, of, and through Samskara. College Literature: A Journal of Critical Literary Studies, 41, 97-119.

Radhakrishnan, R. (2009). Samskara: A reading. In K. C. Baral, D. V. Rao, \& S. P. Rath (Eds.), U. R. Anantha Murthy's Samskara: A critical reader. Delhi: Pencraft International. 